\section{Charles Péguy's flu: the metaphor of diagnosis on the crossroads of historical, sociological and philosophical discourses in 1900}

\author{
Egon Bauwelinck [*]
}

[*] Ghent University, Department of History, Ghent, Belgium.egon.bauwelinck@gmail.com

ORCID: https://orcid.org/0000-0002-3130-6526

\begin{abstract}
This article examines how the French socialist thinker Charles Péguy (1873-1914) used the metaphor of diagnosis of social ills in De la grippe (1900). This text serves as the entrance point into the complex history of the metaphor of diagnosis around the beginning of the twentieth century, as it dwelled in the border regions of historical, sociological and philosophical discourses. Péguy seems at first to follow the contemporary tendency to use the metaphor of diagnosis as a means to denounce ready-made historical and sociological theory. However, the metaphor of diagnosis also foregrounds aspects irreducible to epistemological concerns. The diagnostician thus introduced a paradigm for the frank communication of inconvenient truths from an engaged position, at the same time as the Dreyfus Affair imprinted the persona of the "engaged intellectual" on the modern social imaginary.
\end{abstract}

Keywords: Intellectual history; Diagnosis; Parrhesía; Intellectual engagement.

\section{A gripe de Charles Péguy: a metáfora do diagnóstico no cruzamento dos discursos históricos, sociológicos e filosóficos em 1900}

Resumo: Este artigo examina como o pensador socialista francês Charles Péguy (1873-1914) usou a metáfora do diagnóstico de males sociais em De la grippe (1900). Este texto serve de ponto de entrada para a complexa história da metáfora do diagnóstico do início do século XX, tal como aparecia nas fronteiras dos discursos histórico, sociológico e filosófico. Péguy parece, a princípio, seguir a tendência contemporânea de usar a metáfora do diagnóstico como meio de denunciar a teoria histórica e sociológica então estabelecida. Contudo, a metáfora do diagnostico também enfatiza aspectos irredutivelmente epistemológicos. Este produtor de diagnósticos introduziu, assim, um paradigma para a franca comunicação de verdades inconvenientes a partir de uma comunicação engajada, ao mesmo tempo em que o Caso Dreyfus imprimiu a persona do "intelectual engajado" no imaginário social moderno.

Palavras-chave: História intelectual; Diagnóstico; Parrhesía; Engajamento intelectual. 
$\mathrm{I}$ n 1900, Charles Péguy (1873-1914), a bright French philosophy student and socialist firebrand published the first issue of the journal Cahiers de la quinzaine. ${ }^{1}$ The journal was born out of frustration with the unsatisfying outcome of the Dreyfus Affair, which had polarized public life in the Third Republic for the previous three years. A growing minority of intellectuals had argued that the Jewish army captain Alfred Dreyfus had been the victim of a judicial error when he had been condemned for treason in 1894. The majority of French public opinion had continued to believe in Dreyfus' guilt. Then a student at the École Normale Supérieure, Péguy was an important representative of socialist Dreyfusism. Following the leader of the moderate socialists, Jean Jaurès, socialist Dreyfusists held that socialists had to engage in this struggle for "truth and justice" even if it was not politically expedient. They were opposing a sizable number of French socialist leaders and representatives who ridiculed the Dreyfus Affair as but a case of internecine bourgeois conflict, any engagement in which was a waste of time for a movement concerned with class struggle (Derfler, 2002, pp. 29-37). After a new government granted Dreyfus a pardon in 1899 (an unsatisfying conclusion for the most ardent Dreyfusists), the socialist organizations convened in a national conference to heal divisions within their own movement. The conference issued resolutions affirming the priority of the class struggle over petty bourgeois issues and created a framework for the creation of the unitary socialist party.

Infuriated at the ease with which the majority of the socialist conference participants subtly condemned socialist Dreyfusism, Péguy intended his journal as a forum for what he thought to be its implicit motto: "the social revolution will be moral, or it will not be at all". In the first volume of the journal a trilogy of philosophical dialogues entitled De la grippe, Encore de la grippe and Toujours de la grippe (Péguy, 1987, pp. 401-475) was published. While a remarkable document for the study of the medical metaphors in politics in general, this article examines how Péguy uses the metaphor of physicians making diagnoses, to make sense of his own role with regard to the nascent socialist party. As we will see, Péguy's use of the metaphor of diagnosis seems to anticipate the problems animating this theme issue. In particular, he weaponizes the metaphor to argue against "ready-made" diagnoses of social problems, and to argue for adopting a more empirically sensible attitude of the theorist. However, as the analysis will show, much more is at play than a methodological or epistemological reflection on the relation between theory and history. The metaphor of diagnosis rather allows Péguy to explore the ethical relation between diagnostician and diagnosed.

' I wish to extend my gratitude to both reviewers for their helpful comments on an earlier draft.

2 Unless stated differently, all translations are mine. "La révolution sociale sera morale ou elle ne sera pas." This motto is a pastiche of an utterance ascribed to the founder of the Third Republic, Adolphe Thiers: "La République sera conservatrice ou elle ne sera pas." 
An effective historical description of the present state of the socialist movement requires the same felicity conditions as a medical diagnosis, in particular the commitment of both "patient" and "doctor" to frank speech and sincerity.

The structure of this article is as follows. The first paragraph introduces the dialogue De la grippe and its characters: Charles Péguy himself and the "revolutionary moralist doctor". The second paragraph introduces and contextualizes the text's analogy between politics and health. The third paragraph explains how De la grippe uses the analogy of the doctor's consultation of a patient to denounce the way in which the socialist movement fails to accord a proper hearing to philosophers diagnosing its health. The fourth, fifth and sixth paragraphs put Péguy's use of the metaphor of diagnosis in the context of respectively historical, sociological and philosophical discourses. The metaphor of diagnosis is least compatible with the truth of the historian, since the enunciation of truths about the past from a dispassionate vantage point is more affiliated to the role of the anatomist of a corpse than that of the doctor confronted with a living patient. Péguy is closer to positivist social scientists, who presented themselves as political physicians, intent on not mistreating living base matter and on avoiding "ready-made" diagnoses. However, lastly, De la grippe can be situated in a tradition which highlights the necessity of philosophical diagnoses, identified with frank speech, for a healthy polis.

\section{The Form of the Dialogue and the Revolutionary Doctor}

In the first series of the Cahiers de la quinzaine, Péguy would often publish dialogues dealing with moral questions confronting the socialist labor movement. They feature himself, in a more or less passive role, and a host of more assertive alter ego's: Pierre Baudouin, a pensive philosopher; Pierre Deloire, a serious and slightly pedantic historian; and Péguy's older cousin, a manual laborer who likes to bait and offend his intellectual cousin's pedantic friends (see Vitry, 2014).

De la grippe's opening paragraph shows Péguy in his professional capacity as editor of the Cahiers. Still recovering from a serious case of the flu, he is working from home. The "revolutionary moralist doctor" then enters, to pay his sick friend a visit. The readers of the Cahiers had already encountered the revolutionary moralist doctor. The first issue opened with a mock letter by one of Péguy's "friends", requesting him to say what he thought about people and events pertaining to the socialist movement, and if necessary, to solicit the consultation of "doctors" for difficult cases (Péguy, 1987, p. 297). Docteur, in the first instance, thus simply means a man of learning or academic authority, akin to the docteurs de Sorbonne in Pascal's Provincial letters, to which Péguy often alluded. Obliging his friend, Péguy 
proceeded to consult the "socialist revolutionary moralist internationalist doctor" on an event that had caused a ruckus at the most recent gathering of socialist organizations: a participant had been expelled from the conference venue after insulting Wilhelm Liebknecht. Given the moral subject matter of the consultation ("is it acceptable to heckle party leaders at a conference?"), docteur also recalls the character of the directeur de conscience from Christian pastoral care. The literary form of a "consultation" recalls the example of the romantic poet Alfred de Vigny, whom Péguy had studied at university, and who had created dialogues between the poet Stello and the "black doctor" on the relation between artist and society (Vigny, 1832). De la grippe finally plays on the most obvious meaning of the word docteur as physician, for the doctor soon reveals his true intentions. He has come to visit Péguy to hear him tell the story of his illness, remedy and recovery. "Today, if it doesn't tire you too much, please tell me the story of your illness" (Péguy, 1987, p. 401). The moralist doctor feigns complete ignorance about dealing with disease, since a moralist "never has the flu, on the condition, of course, that he consequently conforms his conduct to his moral teachings" (Péguy, 1987, p. 401). The story of Péguy's illness in De la grippe can be analyzed in two episodes: coming to terms with the fact of being ill, and consulting a doctor for a diagnosis.

\section{Context of the Analogy: Coming to Terms with Illness}

Péguy tells the "doctor" he had experienced his illness as a surprise, given that he had always thought that he would never become ill. This solicits a remark from the doctor which signifies that the whole dialogue is to be understood as an elaborate political allegory. Just as Péguy lived with the baseless hypothesis of his "solidity", "so too societies and political parties vaguely but profoundly believe they are solid" (Péguy, 1987, p. 402). ${ }^{3}$ However, Péguy abandoned this "hypothesis" when confronted with new events. Neither did he "pretend he felt better the more he suffered" (Péguy, 1987, p. 403). ${ }^{4}$ Péguy confesses that since it was the first time he was ill, he took a "puerile pleasure" in his condition. Initially, he amused himself by "playing the role of the sick person". "In the same way bad

3 "Je croyais vaguement et profondément que jeétais solide. - Ainsi les sociétés et les partis croient vaguement et profondément qu'ils sont solides."

4 “Vous n’avez point prétendu que vous alliez d'autant mieux que vous étiez plus douloureusement éprouvé?" - “Je ne l'ai point prétendu." 
revolutionaries take pleasure in novelty when the first agitations of crises perturb the temporarily livable tranquility of the present" (Péguy, 1987, p. 404). ${ }^{5}$

In sum, three attitudes stand in the way of taking a disease seriously and of seeking a diagnosis. The doctor suggests these attitudes are commonplace in dealing with social ills. First, there is simple denial, which the doctor describes as the attitude of people who take refuge in "hypotheses" and pretend "events are wrong" (Péguy, 1987, p. 403). ${ }^{6}$ Secondly, there is a form of complicity in disease: suffering ennobles. Thirdly, there is an attenuated form of complicity in disease, to which Péguy himself fell prey, which consists in taking pleasure in the break from routine. Since Péguy only makes the analogy with "bad revolutionaries" explicit in the last case, we are reduced to speculation as to how exactly the analogy works in the other cases. However, if we take into account the context of the Dreyfus Affair and Péguy's earlier texts, an interpretation readily presents itself.

During the Affair, Péguy had consistently used medical and organic metaphors to talk about the crisis: antisemitism was a disease, the ease with which the people were enlisted by antisemitic campaigns had revealed the extent of the illness, Émile Zola's J'accuse was akin to a surgical procedure, and so on (Péguy, 1987, p. 280). Such metaphors were commonplace. In 1901, for instance, the novelist Anatole France had one of his characters describe the Dreyfus Affair as a "vaccine" revealing the moral ills from which France suffers, "just as the vaccine of Koch reveals in the organism the damages caused by tuberculosis" (France, 1901, p. 124). ${ }^{7}$ Thus Dreyfusism became a question of good health and (moral) hygiene, an episode in the "perpetual attempt to heal a diseased majority by a healthy minority" (Péguy, 1987, p. 457). ${ }^{8}$ The unwillingness of certain socialist politicians to commit to Dreyfus' defense, could consequently be interpreted as following from their incapacity to confront the reality of disease. Within the economy of the medical allegory, the attitude of "denial" towards disease refers to the choice of socialist politicians to treat the Dreyfus Affair as a non-event. The attitude encapsulated by the motto "suffering ennobles" corresponds to the interpretation of those revolutionaries who believed that the Affair was salutary in that it both revealed and hastened the decomposition of the bourgeois regime.

Péguy especially took aim at the latter position. "Suffering ennobles" was the secret core of the catastrophic philosophy of history of self-proclaimed French Marxists, whom Péguy

\footnotetext{
5 “Malade pour la première fois depuis un très long temps, je m’amusais un peu et puérilement de ma situation nouvelle. Ainsi les mauvais révolutionnaires s’amusent de la nouveauté quand les premièress agitations des crises troublent la tranquillité provisoirement habitable du présent."

6 "Vous n'avez point pensée que c'étaient les événements qui avaient tort et l'hypothèse qui avait quand même raison?" 7 "L’Affair a révélé le mal moral dont notre belle société est atteinte comme le vaccine de Koch accuse dans un organisme les lésions de la tuberculose."

8 "[L]e perpétuel essai de la guérison d’une majorité malade par une minorité saine [...]"
} 
referred to as "guesdistes" after their leader Jules Guesde. In their view, according to Péguy, things had to become worse before they could become better: the bourgeois regime had to be pushed to its most ugly limits before it could make way for a new world. Taking his cue from Jaurès, Péguy used organic metaphors to argue a diametrically opposed thesis. The seeds of the future world already existed, in the form of the people constituting the socialist movement itself. The first priority, consequently, should be to take care of the integrity of its members, and to shield them from the ravages of bourgeois habits. "The best means to prepare the birth and life of the socialist world [...] is first to look after the health (garder saufs) of the people who are to become the citizens of the socialist world" (Péguy, 1987, p. 369). ${ }^{9}$ In the same vein, for example, Jaurès had once warned against the dangers of "inoculating in the nascent people the religious hypocrisy of the waning bourgeoisie" (Jaurès, 1899, p. 281)..$^{10}$ Thus, in becoming Dreyfusists, socialists were not merely militating for the reparation of a juridical error; they were at once fighting against their being "contaminated" by unhealthy "bourgeois" habits - the indifference to the distinction between truth and lie, discrimination, racism, ... The will to "garder saufs" the citizens of the future provides the hinge for the introduction of medical metaphors in political analysis. It also readily opens the door for images drawn from a different discourse: that of the care for the salvation (salut) of one's soul. Indeed, during the Affair, Péguy fashioned himself as a moralist directeur de conscience to several of his comrades, fraternally correcting them of their impending "deadly $\sin ^{\prime \prime l}$ to remain at the sidelines of this crisis (Bertrand-Sabiani, 2005). The question of the Christian affiliation of Péguy's and Jaurès' interpretation of socialist self-care is complex, however, since the attitude of "suffering ennobles" can also be assigned a Christian parentage. The relation between socialist self-care, Christian asceticism and pastoral care is the subject matter of the third part of the dialogue, Toujours de la grippe. Since it does not strictly pertain to the metaphor of diagnosis, this relation falls outside of the scope of this article. Elsewhere, I have argued in greater detail how Péguy's metaphors of salvation and good health can be understood in relation to his attempt to develop a "political spirituality", grounding politics in self-care (Bauwelinck, 2019).

We can summarize the first part of Péguy's account of his illness to the revolutionary doctor as follows. A preliminary condition for a diagnosis of a disease, both of the individual corporeal and collective moral varieties, is the choice of the patient to abandon the belief in his invulnerability and other forms of complicity and pleasure in his condition. However,

\footnotetext{
9 "Le meilleur moyen de préparer la naissance et la vie de la cité socialiste [...] [est] d’abord de garder saufs les hommes qui auront à devenir les citoyens de la cité socialiste, et qui sont qualifiés pour devenir ces citoyens."

10 "[E]t on essaierait ce crime: inoculer au peuple naissant l'hypocrisie religieuse de la bourgeoisie finissante."

"Péguy had written of president Faure, who had failed to grant a pardon to Dreyfus following Émile Zola's open letter, that "he had died in the state of deadly sin" (PÉGUY, 1987, p. 213).
} 
as the presence of this theme of attitudes to health and illness in the later parts of the dialogue attests, a concern for one's good health is also more than a preliminary condition. It accompanies and conditions the whole process of accepting one's illness, seeking diagnosis and applying remedies.

\section{Calling for a Doctor}

After Péguy had come to terms with being ill, his family invited a doctor to see him. At this point in the story, the revolutionary doctor ironically contrasts Péguy's care for his health with the way in which political parties examine their health.

That is extraordinary, my friend: what! you were gravely ill and you called for a doctor! [...] What were you thinking? [...] What a strange idea! How you neglect the advantages of the parliamentary regime. We on the other hand, when a party is sick, studiously avoid appealing to doctors: they could diagnose sharpened individual ambitions, boulangitis [a synonym of demagoguery, after the populist leader General Boulanger], parlementaritis, concurrencitis, autoritarity, unitarity, electorolatria better called: electoroculture; we don't want any of that; thus we proceed to convene in conferences the sick people, who are numerous, the healthy people, who are less numerous, and the doctors, who are rare. The sick people have one to five votes, the healthy people have one to five votes, the doctors have one to five votes [...] Then the majority decides. (Péguy, 1987, p. 406) ${ }^{12}$

I have indulged in a lengthy citation to show how the analogy, now very explicit, starts to function. Step by step, the conditions of felicity of a diagnosis, which functions both as judgment on one's health and as prerequisite for a remedy, are elucidated. They are gradually contrasted with how the socialist party relates to the truth of its own condition. In this way the dialogue about the physician's diagnosis, itself leads up to a paradoxical meta-diagnosis: there is no place for diagnosis in the socialist movement.

\footnotetext{
12 “Voilà qui est extraordinaire, mon ami: comment! vous étiez gravement malade, et vous avez demandé le médecin! [...] Étrange idée! et comme vous connaissez peu les avantages du régime parlementaire. Nous, quand un parti est malade, nous nous gardons soigneusement de faire venir les médecins: ils pourraient diagnostiquer les ambitions individuelles aigues, la boulangite, la parlementarite, la concurrencite, l'autoritarite, l'unitarite, l'électorolâtrie, mieux nommée ainsi: électoroculture; nous ne voulons pas de cela; nous réunissons donc dans des congrès les malades, qui sont nombreux, les bien portants, qui sont moins nombreux, et les médecins, qui sont rares. Les malades ont de une à cinq voix, les bien portants de une à cinq voix, les médecins de une à cinq voix. [...] Puis la majorité décide."
} 
As this citation shows, this conclusion is inseparable from Péguy's experience of disappointment with the outcome of the socialist conference. He was neither the last, nor the first philosopher to retreat from an experience of democracy into writing dialogues that rigorously separate Truth from democratic opinion. Indeed, the founding gesture of philosophical discourse as such, could be connected with Socrates' and Plato's disappointment in Athenian democracy. However, both because Péguy is a child of the $19^{\text {th }}$ century and because he chooses the metaphor of diagnosis, he remains in thrall to an ambiguity that obstructs a simple reading of this text as an apology for "philosophical" truth and as a discourse against democratic opinion. If the Dreyfus Affair taught us anything, Péguy held, it is that majorities and public opinions are not at all impervious to error. What kind of truth has nothing to gain by appealing to "public opinion" and is indifferent to the judgment of majorities (Péguy, 1987, pp. 196-199)? The truth which the Dreyfusists had defended was this kind of truth: it was "the scientific truth, the historical truth, the truth itself, the truth". "We took pride [...] to conduct ourselves in this Affair which embraced us alive, as perfect historians" (Péguy, 1987, p. 295)..$^{13}$ The crucial question then is to what extent the truth of the doctor's diagnosis can be reduced to this "scientific truth, the historical truth, the truth itself, the truth". In choosing the metaphor of diagnosis, does Péguy simply highlight the need for a scientific, historical judgment on the present situation of the socialist movement, or is something else at play?

\section{Diagnosis and Historical Truth: Truth of an Enunciation and Enunciation of Truth}

At first sight, the metaphor of diagnosis does appear to underline the scientific character of the truth Péguy wishes to protect against the conditions of democratic opinion. However, such an interpretation underestimates the complexities of the metaphor of diagnosis in $19^{\text {th }}$ century discourse, a point to which we will return in the fifth paragraph. Before returning to De la grippe to elucidate our problem of how the doctor's diagnosis relates to the Dreyfusist historian's scientific truth, it is worth noting that Péguy had already suggested that the scientific truth of the historian and the truth of the Dreyfusists are not entirely indistinguishable in an earlier text, "Le Ravage et la Réparation", published in La Revue blanche of 15 November 1899.

13 "[L]a vérité scientifique, historique, la vérité même, la vérité. [...] Nous nous faisions gloire [...] de nous conduire, dans cette Affair qui nous étreignait vivants, comme de parfaits historiens." 
"Ravage and reparation" was a response to an interpretation of the Affair by the figurehead of positivist national history, Ernest Lavisse. Lavisse had argued that the antidreyfusards, as representatives of France's past of military honor and nationalist pride, would seek reconciliation with the Dreyfusists, the representatives of France's future of advances in the (human) sciences and institutional procedures. This reconciliation would elevate France to a higher synthesis. Péguy argued that reconciliation was an inappropriate concept, since it required two parties to be at the same level. The Affair, however, had simply pitted a sane minority against an unhealthy majority: "What is at hand is therefore not a reconciliation [...] only healing, medicine and hygiene, recovery, health, propriety and cleanliness. A reconciliation between the anti-Semites and us, is as inappropriate as a reconciliation in Lisbon between doctor Calmette and the plague bacteria" (Péguy, 1987, p. 280). ${ }^{14}$

Paradoxical though it may seem, the historian's truth is more affiliated to a juridical imagination of society than that of the Dreyfusist. Conflict is but a temporary disturbance of order and can be reconciled contractually. The Dreyfusist's truth however, is a moment within a perpetual struggle for health and against disease. As such, it is correlative of a vision of society as unending strife. The Dreyfusist's truth is necessarily spoken from a subject position engaged in an ongoing struggle, while the historian-conciliator lays claim to a truth spoken from outside "about" a struggle, akin to the truth of an impartial judge. Even before he apparently confounded them in the first issue of the Cahiers, Péguy seemed aware of an essential incompatibility between truth-as-diagnosis and the "scientific, historical truth". It is noteworthy that this incompatibility is articulated precisely through the images of healing, medicine and hygiene.

For a while, however, this incompatibility was left obscured. Confronted with the uneasy fact that not all historians had respected the "historical, scientific truth" enough to become Dreyfusists, Péguy rationalized it by faulting them for being bad historians:

I had a historian friend, a very good student at the Sorbonne, who, I have been told, has become an antidreyfusard. [...] I wondered how this miserable person, so oblivious of his present, dared to study past events. [...] We have doubtless been made to write good and sensible dissertations on this theme: that we are able to write the history of past times and that we cannot write the history of the present (l'histoire du temps présent), because whereas we are impartial with regard to the past, we are necessarily partisan with regard to the present. Yet it is us, to the contrary, who are the [real] historians! who have become historians! What insight we have gained into what constitutes a

14 “|I ne s'agit donc pas d'une réconciliation [...] II ne peut s'agir que de guérison, de médecine et d'hygiène, de redressement, de santé, de propreté, de salubrité. II n’y a pas plus lieu de nous réconcilier, les antisémites et nous, qu'il n'y avait lieu de réconcilier à Lisbonne le docteur Calmette et le microbe de la peste." 
people, what an idea is, what a campaign is, what a crisis is, what a revolution looks like! (Péguy, 1987, pp. 266-267)

A prerequisite for historical knowledge, Péguy believed in 1899, is engagement in present action. Knowledge of the present functions as a kind of illumination, retrospectively shedding new light on the past (Péguy, 1987, p. 279, 282-283). It is not difficult to see how this thesis, when radicalized, could come to undermine the very legitimacy of "historians" pontificating about present affairs. And radicalize it did. Channeling Nietzsche's contempt for "armchair general" historians (Nietzsche, 1995, pp. 83-168) in the Second untimely meditation, Péguy would in later texts sharply distinguish between the engaged "memory" of the chronicler and the truth of the "historian", who is anything but rooted in his own time (Péguy, 1991, p. 1183). Read as a judgment of value, this statement doesn't do justice to the discipline of history in the beginning of the $20^{\text {th }}$ century, and it is to be noted that Péguy counted many historians among his friends (for example: Gabriel Monod). Rather than referring to all historians, the name "historian" in Péguy's later texts functions as a kind of conceptual persona, referring to the subject position of anyone who speaks truth about a subject matter without taking the slightest risk or responsibility.

The term of "historical truth", which Péguy so proudly cites in the opening issue of the Cahiers de la quinzaine, thus hides a tension between engaged and disengaged truth, between truth in the present and truth about the past. It is precisely the metaphor of diagnosis which brings out this hidden tension. We can compare the "historian" with the figure of the anatomist who retrospectively determines the cause of death. The anatomist might very well vindicate the diagnoses the patient's doctors had made when he was still alive. "He did indeed die of liver cancer." The fact that the anatomist is dealing with a corpse however, betrays that what is at stake in the enunciation of truth has changed. It is noteworthy that an eminent medievalist from the early twentieth century expressed this difference in nature in the idiom of medicine. Expressing his discomfort with writing about contemporary history, Henri Pirenne wrote: "He [the contemporary historian] is reduced to judging appearances, like a physician faced with a living body. To give a truly scientific account of an

15 “J'avais un camarade historien, très bon élève en Sorbonne, et qui, à ce que l'on ma dit, est devenu antidreyfusard. [...] Je me demandais comment un malheureux, inintelligent à ce point du présent, osait ainsi étudier les événements passés. [...] Sans doute on nous a fait faire des dissertations bien sensées sur ce thème: que nous pouvons bien faire l'histoire des temps passés et que nous ne pouvons pas faire l'histoire du temps présent, parce que nous sommes impartiauxà l'égard des temps passés, tandis que nous sommes forcément partiauxs à l'égard du temps présent. Comme c'est nous, au contraire, qui sommes les historiens! qui sommes devenus historiens. Quelle connaissance nous avons reçue de ce que c'est qu'un peuple, de ce que c'est qu'une idée, de ce que c'est qu'une campagne, de ce que c'est qu'une crise, de ce que c'est qu'une révolution." 
epoch, it has to be dead so that one can rummage through its entrails, in the way that an anatomist dissects a corpse" (Pirenne, 1932, p. ix). ${ }^{16}$

Another way to tease out this extra dimension which the metaphor of diagnosis reveals underneath the term of "historical, scientific truth", is to shift attention away from the truth enunciated to the enunciation of truth. For example: although the truth value of the proposition "Dreyfus was innocent of the charge of treason" remains constant from the point of view of "scientific, historical truth", clearly something different is at stake when saying it as a militant advocating for Dreyfus' freedom in 1898, or as a historian in 2020. In the first case, the enunciation of truth is inseparable from a diagnosis of an "ill" society that could condone this injustice; it is an expression of the desire of not becoming complicit in injustice through silence; it is a moment in the recovery from the "illness". When exploring the functioning of the metaphor of diagnosis, we have to be attentive to the conditions of the enunciation of a truth as much as to the more narrowly epistemological and methodological question of the truth of an enunciation. It is precisely considered as a mode of enunciation of truth, that the doctor's diagnosis becomes irreducible to the historian's "scientific truth, the historical truth, the truth itself, the truth", and that De la grippe can be situated in a series of apologies of philosophical discourse. Before examining this relation, we need to explore the connection between Péguy's critique of ready-made diagnoses and the discourse of social science.

\section{Diagnosis and Sociological Truth: The Critique of Ready-made Diagnoses}

With feigned naiveté, the revolutionary doctor asks details about the nature of the consultation. The doctor, Péguy explains, attentively examined his body, checked his pulse, listened to his chest, touched his back. The revolutionary doctor responds that the diagnosis of social ills proceeds differently. To find out what is happening and what will happen, socialist theorists simply refer to authors that are long dead, such as Karl Marx (1994, I, p. 408). In this criticism, we can easily discern an echo of contemporary Marxist revisionism, which argued that Marxist concepts and predictions needed to be confronted with new facts. Péguy personally knew the most notable French revisionists, Georges Sorel and Charles Andler. The metaphor of diagnosis thus serves to represent the right relation

\footnotetext{
16 "Plus l'historien se rapproche du présent, plus sa tâche devient malaisée. [...] II juge sur des apparences ainsi que le médecin devant un corps vivant. Pour pouvoir scientifiquement se rendre compte d’une époque, il faut qu'elle soit morte et que l'on puisse fouiller les entrailles comme l'anatomiste qui dissèque un cadavre."
} 
between theory and the empirical examination of "cases”. The doctor didn't diagnose his patient standing on the threshold of the door, saying "most certainly, sir, you have the flu: we know what it is; it's well-known, classified, labeled, I have a printed formula, copied from a good book, that infallibly guarantees recovery" (Péguy, 1987, p. 408). ${ }^{17}$ To the contrary, the doctor exclaims that it's an "extraordinary illness! I haven't seen two cases that resembled each other" (Péguy, 1987, p. 411).$^{18}$ Commenting this exclamation, the revolutionary doctor and Péguy discuss a formula they remember from their schooldays. "There are no illnesses, only ill people." (Il n'y a pas de maladies, il n'y a que des malades.)

The history of this phrase reveals that a good deal more is at stake than simply a plea for a more empirically sound theory. The phrase is attributable to the forefather of homeopathy, Samuel Hahnemann (1755-1843). His disciples interpreted this phrase as an indictment of the vain desire to make diagnoses. "Except in a few acute diseases no diagnosis can be made, and no diagnosis need be made except that the patient is sick," the physician James Tyler Kent explained in 1900. "The more one thinks of the name of a disease so-called the more one is beclouded in the search for a remedy" (Kent, 1919, p. 24). General and ready-made remedies for clearly defined diseases should make way for treatment that is both individualizing and holistic. The French positivists shared the homeopaths' distrust of general diagnoses. "Since the illness is always individual", Jean-François Robinet summarized the thought of his teacher Auguste Comte, "and since it doesn't conform enough with the abstract types which theoretical reason constructs, the sick person himself is ultimately the best judge of his own condition". True to his convictions, Comte had devised his own diet and regime when suffering from stomach cancer, relegating physicians to the role of advisers. On his deathbed, he confided the paradox to Robinet as follows: "medicine presents an essential logical vice, since it is reduced to having recourse to general procedures in specific cases" (Robinet, 1891, pp. 276-277).${ }^{19}$ Some positivists drew political conclusions from this aphorism. Eugène Sémérie, for instance, interpreted it as a rejection of the tutelage exerted over society by those who pretend to possess ready-made and abstract remedies for its ills (Sémérie, 1870, pp. 44-45). This interpretation of the aphorism as a general defense of (political) autonomy is not surprising, if we recall that submission to the physician is one of the three examples Immanuel Kant gave of the condition of immaturity in his article on the

\footnotetext{
17 "Il ne me dit pas du seuil de ma chambre: 'Parfaitement, monsieur, vous avez la grippe: nous savons ce que c'est; c'est connu, classé, catalougé, jai là une formule imprimée, copiée dans un bon livre, et qui assure infailliblement la guérison'." 18 "Quelle maladie extraordinaire! je n'ai pas encore vu deux cas qui se ressemblaient."

19 "A ce nouveau point de vue, la maladie étant toujours individuelle, et ne concordant pas assez avec les types abstraits construits par la raison théorique, le malade reste le meilleur juge de sa situation. C'est ce qui fut formulé par notre Maître, pendant sa maladie, dans cet aphorisme important: La médecine présente un vice logique essentiel, puisqu'elle est réduite à recourir à des procédés généraux dans des cas spéciaux."
} 
nature of Aufklärung: "if I have a book, that thinks for me, a pastor that has a conscience for me, a doctor, who judges my diet for me, and so on, then I don't have to concern myself about myself" (Kant, 1917, p. 35). ${ }^{20}$

As the history of the phrase il n'y a pas de maladies, il n'y a que des malades shows, there is more at stake than the call for a more empirically sound classification of pathologies. At issue is the very legitimacy of having recourse to a second person to find out the truth about oneself. Translated to social ills, the aphorism similarly doesn't simply call for better (historical or sociological) "theory", but questions the very role of the theorist. Behind the criticism of ready-made diagnoses, lies the fear of abstract, unrealistic and arbitrary blueprints imposed on societies by detached outsiders.

Although for many 19th century conservatives and revolutionaries the fear of arbitrary designs imposed on society was inseparable from a more or less vague memory of the Jacobins, it was of course a much older theme in Western political science. Aristotle tried to conjure it through the metaphor of craftsmanship. ${ }^{21}$ The statesman couldn't do whatever he wanted: his hands were necessarily tied by something which Aristotle referred to as hylè, a name for matter resisting the craftsman's designs (Aristotle, 1998, p. 198, 132al). ${ }^{22}$ Plato has been cast by modern commentators as the forefather of modern Jacobins, animated by the desire to impose a blueprint on society. But even he recognized that the realization of the Republic in actually existing historical societies would entail a compromise with a limit that escapes the control of the guardians: the rhythm of the cosmos. People would procreate at an unpropitious moment; the children of such unions would be of a lesser alloy; a generation of guardians of lesser quality would take up stewardship and the Republic would be on its way to a process of degeneration (Plato, Republic, 545d-547c).

There is a history to be written about the way in which in the 19th century, organic metaphors such as Plato's became more important than the Aristotelian metaphor of craftsmanship to condemn arbitrary, utopian blueprints imposed without regard for circumstances. To remind ourselves that this fear of detached utopianism was shared by conservatives and revolutionaries alike, we need only cite Marx' Eighteenth Brumaire: "men make their own history, but they do not make it just as they please; they do not make it under

\footnotetext{
20 "Habe ich ein Buch, das für mich Verstand hat, einen Seelsorger, der für mich Gewissen hat, einen Arzt, der für mich die Diät beurtheilt, etc., so brauche ich mich mich ja nicht selbst zu bemühen."

${ }^{21}$ Remarkably, even a commentator as subtle as Hannah Arendt has failed to appreciate how the metaphor of craftsmanship served to highlight the limits of the statesman's action, rather than advocating the limitless power of his blueprint (ARENDT, 1958, p. 153).

22 "For other craftsman - for example, a weaver, or a shipbuilder - should also be supplied with suitable material [hylè] to work on, and the better the material that has been prepared, the finer the product of their craft must necessarily be. So too a statesman or legislator should be supplied with proper material [hylè] in a suitable condition."
} 
circumstances chosen by themselves but under circumstances directly encountered, given and transmitted from the past" (Marx, 1994, p. 188). Whether these "circumstances not chosen by men" receive the name "historical process" or "society as an organism", the point remains that the statesman or revolutionary risks deforming his people if he does not first study it as the base material of his action. The classic paradigm of deformation by blueprint, is Rousseau's assessment of the reforms of Peter the Great as artificial and imported designs forced on an "immature" people. ${ }^{23}$ Interestingly, we find echoes of this motif in social-democratic interpretations of the Russian revolutions of the early twentieth century. Péguy's assessment of the Russian revolution of 1905, for example, channels both the Aristotelian metaphor of craftsmanship and the Platonic language of organic growth. He faults the Western-educated Russian revolutionaries for having neglected both the "notion [...] of a matter, an inexpressible residue of matter that negates and limits the [realization of] the idea" (Péguy, 1989, p. 92)24 and the "problems of childhood, youth, old age, growth and maturation, aging, birth and death, sickness, degeneration [...]" (Péguy, 1989, p. 94). ${ }^{25}$

Although equally effective in conjuring the "blueprint" imagination of political action, organic metaphors have one downside compared with the metaphor of craftsmanship: they tend to disqualify all political actions as artificial intrusions in a natural process. This is precisely why, as Schlanger has shrewdly observed (see also Braunstein, 2015), the metaphor of medicine became so crucial for 19th century social science:

The idea of political medicine as both respect and maintenance of the spontaneous regulation of a living body is the hinge of social theory and political practice. Only in this way do the naturalist theses, which forbid any form of voluntary intervention, avoid condemning themselves to the passive contemplation of political developments. This no doubt explains the central importance of the medical themes of hygiene and

\footnotetext{
23 "La jeunesse riest pas l'enfance [...] II est pour les nations comme pour les hommes un temps de jeunesse ou, si l'on veut, de maturité, qu'il faut attendre avant de les soumettre à des lois" (ROUSSEAU, Du contrat social ou principes du droit politique, chapitre VIII, cited in SCHLANGER, p. 182).

24 "Nous rejoignons ici la vieille idée platonicienne, d'une matière, d'un résidu inexpressible de matière, négation et limitation de lidée." Péguy's use of the adjective platonicienne instead of Aristotelian can be called a lapsus. The concept of hylè was in any case the subject of an extensive commentary in Henri Bergson's lessons at the Collège de France of 3 February 1905, a few months before Péguy's interpretation of the Russian Revolution of 1905. There, Bergson defined hylè in quasi-identical terms as "un principe d'indétermination, quelque chose qui empêche les Idées platoniciennes" (BERGSON, 2017, p. 123).

25 "Les problèmes de l'enfance, de la jeunesse, de la vieillesse, de la croissance [...] et de la maturation, du vieillissement, de la naissance et de la mort, de la maladie, de la décroissance [...]"
} 
pathology in naturalist thought: only they allow for a doctrine of political action. (Schlanger, 1995, p. 176) ${ }^{26}$

I would go a step further, and suggest that the pose of the natural scientist and of the physician didn't imply society as an organism. For instance, true to Marxist tradition, Georges Sorel abhorred the sociological metaphor of society as an organism, as he thought it passed over essential strife within society. Nonetheless, haunted by a distaste of what he called "blanquist" utopianism, Sorel also advocated studying the socialist movement as if it were a natural phenomenon (l'étudier comme un phénomène naturel) (Sorel, 1899, p. 280). Interpretations which were prescriptive as well as descriptive betrayed the secret temptation to lead (conduire) the people, and couldn't lay claim to the dignity of a truly "philosophical interpretation". Although he completely rejected the Comtian model of societal development as beholden to laws, he might very well have subscribed to Comte's dictum that "it's not a question of governing phenomena". ${ }^{27}$

In taking up the metaphor of diagnosis Péguy granted the philosopher a more assertive role than Sorel. The revolutionary doctor ends up lecturing his interlocutor on the sterility of the dictum that "there are no diseases, only sick people". There are both diseases and sick people. "Because there are illnesses, we have to research in documents and books. Because there are sick people we have to listen to their chests individually or particularly" (Péguy, 1987, p. 411). ${ }^{28}$ The role of theory, and with it the role of the philosopher in social diagnoses, are thus safeguarded. At the same time, the provision that the philosopher-physician cannot content himself with ready-made diagnoses conjures the specter of governing phenomena through arbitrary theory.

\section{Diagnosis and Philosophical Truth: The Truth-game of Diagnosis}

As the analysis has shown, the metaphor of diagnosis allowed Péguy to foreground a number of dimensions of truth-telling irreducible to the epistemological and

\footnotetext{
26 "L'ídée de la médecine politique comme respect et maintien de la régulation spontanée d'un corps vivant est au pivot de la théorie sociale et de la pratique politique. C'est par là seulement que les thèses naturalistes, qui interdisent toute une dimension d'intervention volontaire, ne se condamnent pas à la contemplation passive du devenir politique. A cela tient sans foute l'importance centrale des thèmes médicaux, hygiène et pathologie, dans les perspecives naturalistes: eux seuls permettent de déboucher sur une doctrine d’action politique."

${ }^{27}$ The full citation reads: "II ne s’agit pas de gouverner les phénomènes, mais seulement d'en modifier le développement spontané; ce qui exige évidemment qu'on en connaisse préalablement les lois" (cited in SCHLANGER, 1995, p. 177).

28 "C'est parce qu'il y a des maladies qu'il faut que l'on travaille dans les documents et dans les renseignements des livres. C'est parce qu'il y a des malades que nous devons les ausculter individuellement ou particulièrement."
} 
methodological considerations of a (social) scientist or historian. Like the historian, the diagnostician attempts to tell the non-partisan truth about phenomena, yet his truth is a moment in the search for remedy and the restoration to good health. The diagnostician shares the social scientist's disdain of ready-made theories, but he stops short of condemning all of his activities as arbitrary and heterogeneous interventions in a natural process.

There is a third layer of the metaphor of diagnosis. In establishing and communicating the truth of the patient's condition, during the whole consultation, the doctor needs to have the courage to disregard the patient's ego. The doctor needs to ask private and uncomfortable questions to obtain the necessary clues for a diagnosis; he needs to communicate the unpleasant diagnosis to the patient and sometimes prescribe unsavory remedies. The patient, similarly, cannot afford to lie or dissimulate to his doctor. He too has to put aside his ego, answer truthfully and allow the doctor to tell him the truth. The condition of felicity for a consultation and the making of a diagnosis is the rule of mutual truthfulness:

Doctors always tell the truth.

- Let us not generalize [,the revolutionary doctor says]. Let us grant that they naturally say the truth; let us grant that they tell the truth when you really want to know it. (Péguy, 1987, p. 412) 29 $^{29}$

This truth game is precisely what malfunctions in the socialist worker's movement. Its problem is not a lack of theory, nor the incorrect application of theory. Its problem is that a concern for ego has crowded out a concern for truthfulness. The sick are afraid of hearing the unflattering truth about their condition and excel in hiding their own bad health. The doctors are afraid of asking the necessary questions, of reaching unpleasant diagnoses and of communicating inconvenient truths. Péguy uses a concept from $17^{\text {th }}$ century moralist literature to "diagnose" the culprit: amour-propre. Opposed to amour de soi, which means a respectable care for one's own health and subsistence, amour-propre referred to the morbid concern for other people's opinions about oneself (Mauroy, 2014).

We please! We are pleasant! We say pleasant words and not true words. We aim to please everyone. [...] We respect the amour-propres and sometimes we [even] flatter them. (Péguy, 1987, p. 413) ${ }^{30}$

\footnotetext{
29 “[L]es médecins disent toujours la vérité. - Ne généralisons pas trop. Admettons seulement qu’ils disent naturellement la vérité; admettons qu'ils disent la vérité quand on veut bien la savoir."

30 "Nous plaisons! Nous sommes plaisants! Nous disons des paroles plaisantes et non pas des paroles vraies. Nous plaisons à tout le monde [...] Nous respectons les amour-propres et quelquefois nous les flattons."
} 
The diagnosis which concludes the dialogue of De la grippe is that the failure of the socialist worker's movement to practice courageous truthfulness cuts it off from the truth of its own condition, condemning it to a mirror palace of appearances:

- We behave more ingeniously in the case of social illnesses: we carefully avoid criticizing appearances; as long as the membership is numerous [...] as long as congresses finish singing the Internationale [...] we studiously avoid to examine what is underneath, we carefully avoid examining if the souls are in good socialist health or if they are contaminated with bourgeois illness (Péguy, 1989, pp. 414-415) $)^{31}$

The metaphor of diagnosis in the end emphasizes the importance of the inconvenient truth of the philosopher, who speaks with frankness (franchise). I have explored elsewhere (Bauwelinck, 2019, pp. 11l-199) the way in which Péguy elaborated on the concept of frankness. Here, it suffices to remark that he was well aware of the fortunes of the equivalent Greek concept of parrhesía and tended to identify it with the proper activity of philosophers. ${ }^{32}$ Already in the second issue of the Cahiers de la quinzaine, he had recalled the locus classicus of the exercise of frank speech: Plutarch's description of Dio courageously speaking his mind to the tyrant of Syracuse (Péguy, 1987, pp. 347-348). Just as the sovereigns of old needed philosophers boldly speaking their mind, so too the socialist worker's movement needed to safeguard a space for the frank truth spoken at a risk to oneself.

This connection of the metaphor of diagnosis with the practice of frankness reveals the affinity of De la grippe to a broader corpus of texts. Social science was not the only modern discipline to draw heavily on the metaphor of diagnosis. A detailed history remains to be written about how a strand of modern philosophers too elevated diagnosis into a paradigm for their interventions, often to distinguish themselves from social scientists and historians. Two well-known reference points suffice to illuminate this tradition. Nietzsche's Second untimely meditation (Nietzsche, 1995, pp. 83-168) is arguably the best example of a philosophical "diagnosis" of the present. The text distributes the role of making diagnoses (ibid., p. 85) to the "philosopher as physician of culture". The historian appears as the subject of the diagnosis, exemplifying more than others modern man's affliction: the "historical illness". Nietzsche's identification of diagnosis with the proper task of philosophy was not lost on a second author of crucial importance in the elaboration of the metaphor, Michel Foucault.

\footnotetext{
31 "Nous en usons plus astucieusement pour les maladies sociales: nous nous gardons soigneusement de critiquer les apparences; pourvu que les groupes soient nombreux [...] pourvu que les congrès finissent en chantant L'Internationale [...] nous nous gardons soigneusement d'examiner ce qu'il y a là-dessous, nous nous gardons soigneusement d'examiner si les âmes jouissent de la santé socialiste ou si elles travaillent du mal bourgeois."

32 Neveu (2017) and Coustille (2018, pp. 98-100) have recently also interpreted Péguy's Cahiers as an exercise in parresía.
} 
Although he might have coined the phrase "the history of the present", Foucault more consistently presented himself as a diagnostician and as such as a philosopher, e.g.: "That what I do has something to do with philosophy is quite possible, especially in so far as, at least since Nietzsche, philosophy has as a task to make diagnoses [...] I try to diagnose, to effectuate a diagnostic of the present [...] in this sense I can call myself a philosopher" (Foucault, 200la, l: p. 634). ${ }^{33}$

As soon as the historian attempts to diagnose the present and answer the question "who are we today? what is the today we are living?", Foucault believes he is entering the terrain of the "particular activity of philosophy" (Foucault, 200la, l: p. 641). ${ }^{34}$ Foucault's later genealogy of philosophical discourse, connecting it with the exercise of frank speech (parrhesía) (Foucault, 2008, 2009), similarly pivoted on his discovery of 1982 that Hellenistic philosophers cast themselves as doctors of the soul capable of diagnosing passions with intransigent frankness. ${ }^{35}$

In France in 1900, as the character of the modern "intellectual" and the concept of "engagement" were in the process of imprinting themselves on the modern social imagination (Charle, 1990), the function of the metaphor of diagnosis was more fluid. Philosophers had not yet employed it so explicitly to define "their particular activity". In exploiting the many layers of the metaphor of diagnosis to conceptualize his relation to the socialist workers' movement, Charles Péguy nonetheless foregrounded aspects irreducible to the epistemological concerns of historians or sociologists. While the metaphor unequivocally serves as an endorsement for the right balance between theory and the observation of particular cases, it calls above all for the right mode of telling the truth about one's present. The diagnostician functions as a paradigm for the sincere engaged intellectual, taking the risk of displeasing his audience and considering his truth as a moment of struggle against bad habits.

\footnotetext{
33 "Que ce que je fais ait quelque chose à voir avec la philosophe est très possible, surtout dans la mesure où, au moins depuis Nietzsche, la philosophie a pour tâche de diagnostiquer [...] Je cherche à diagnostiquer, à réaliser un diagnostic du présent [...] en ce sens je puis me déclarer philosophe" (emphasis mine.)

34 The full citation reads: "En outre, Nietzsche a découvert que l'activité particulière de la philosophie consiste dans le travail du diagnostic: que sommes-nous aujourd'hui? Quel est cet 'aujourd'hui' dans lequel nous vivons? Une telle activité de diagnostic comportait un travail d'excavation sous ses propres pieds pour établir comment seétait constitué avant lui tout cet univers de pensée, de discours, de culture qui était son univers".

35 The theme of frank speech appears in Foucault's analysis of Galen's Treatise on the passions of the soul and its errors in the lesson of March 10, 1982 (FOUCAULT, 2001b)
} 


\section{References}

ARISTOTLE. Politics. Translated by C. D. C. Reeve. Indianapolis: Hackett Publishing Company, 1998.

ARENDT, Hannah. The Human Condition. Chicago: The University of Chicago Press, 1958.

BAUWELINCK, Egon. Devleesgeworden ziel: Politieke spiritualiteit en moderniteit in het werk van Charles Péguy (1873-1914). 2019. Doctoral dissertation - Universiteit Gent. Gent, 2019.

BERGSON, Henri. L'évolution du problème de la liberté: Cours au Collège de France 1904-1905. Arnaud François (éd.). Paris: Presses Universitaires de France, 2017.

BERTRAND-SABIANI, Julie. Lettres de Péguy à Camille Bidault (1890-1899). Amitié Charles Péguy, v. 28, nr. 109, pp. 3-64, 2005.

BRAUNSTEIN, Jean-François. La philosophie de la médecine d'Auguste Comte: Vaches carnivores, Vierge Mère et morts vivants. Paris: Presses Universitaires de France, 2015

CHARLE, Christophe. Naissance des "intellectuels", 1880-1900. Paris: Éditions de Minuit, 1990.

COustille, Charles. Antithèses: Mallarmé, Péguy, Paulhan, Céline, Barthes. Paris: Gallimard, 2018.

DERFLER, Leslie. The Dreyfus Affair. Westport, CT: Greenwood Press, 2002.

FOUCAULT, Michel. Dits et écrits, 1954-1988. François Ewald \& Daniel Defert (éd.). 2 v. Paris: Gallimard, 200la.

FOUCAULT, Michel. Le gouvernement de soi et des autres: Cours au Collège de France 1982-1983. François Ewald, Frédéric Gros \& Fontana (éd.). Paris: Gallimard, 2008.

FOUCAULT, Michel. Le gouvernement de soi et des autres II. Le courage de la vérité: cours au Collège de France 1983-1984. François Ewald, Frédéric Gros
\& Alessandro Fontana (éd.). Paris: Gallimard, 2009.

FOUCAULT, Michel. L'herméneutique du sujet: cours du Collège de France, 1981-1982. Frédéric Gros (éd.). Paris: Seuil, 200lb.

FRANCE, Anatole. Histoire contemporaine, Mr. Bergeret à Paris. Paris: Calmann-Lévy, 1901.

JAURÈS, Jean. L'enseignement laïque et l'enseignement clérical. In: JAURÈS, Jean. L'action socialis te. Paris: Georges Bellais, 1899.

KANT, Immanuel. Beantwortung der Frage: Was ist Aufklärung? In: KANT'S Gesammelte Schriften. Berlin: Reimer \& de Gruyter, 1917. vol. 8, pp. 33-42.

KENT, James Tyler. Lectures on Homeopathic Philosophy. Chicago: Ehrhart \& Karl, 1919.

MARX, Karl. Selected writings. Ed. Lawrence H. Simon. Indianapolis: Hackett Publishing Company, 1994.

MAUROY, Hervé. L'amour-propre: une analyse théorique et historique. European Journal of Social Sciences, v. 52, nr. 2, pp. 73-104, 2014.

NEVEU, Franck. Fondements philosophiques et forme discursive de l'anti-sociologisme de Péguy. Amitié Charles Péguy, v. 40, nr. 159, pp. 268-284, 2017.

NIETZSCHE, Friedrich. On the Utility and Liability of History for Life. In: THE COMPLETE Works of Friedrich Nietzsche. Stanford, CA: Stanford University Press, 1995. II: Unfashionable Observations. Translated by Richard T. Gray. pp. 83-168.

PÉGUY, Charles. (Euvres en prose complètes. Robert Burac (éd.). 3 vols. Paris: Gallimard, 1987 [I], 1989 [II], 1991 [III].

PIRENNE, Henri. Histoire de Belgique: De la révolution de 1830 à la guerre de 1914. Brussels: Lamertin, 1932. 
PLATO. Republic. G. R. F. Ferrari (ed.); translated by Tom Griffith. Cambridge, UK: Cambridge University Press, 2000.

ROBINET, Jean-François. Notice sur l'œuvre et sur la vie d'Auguste Comte. Paris: Société positiviste, 1891.

SCHLANGER, Judith E. Les Métaphores de l'organisme. Paris: L'Harmattan, 1995.

SEMERIE, Eugène. La médecine. In: ALMANACH de l'Encyclopédie générale. M. Alcan (éd.). Paris:
Bureau de l'Encyclopédie Générale, 1870. pp. 44-45.

SOREL, Georges. Éthique du socialisme. Revue de Métaphysique et de Morale, v. 7, nr. 3, pp. 280-301, 1899.

VIGNY, Alfred de. Les consultations du docteur-noir. Première consultation: Stello ou les diables bleus. Paris: Gosselin et Renduel, 1832.

VITRY, Alexandre de. Péguy pseudonyme. Nunc, nr. 32, pp. 34-42, févr. 2014. 